\title{
Perlindungan Transformasi Karya Cipta Lontar Dalam Bentuk Digitalisasi
}

\section{Dewa Ayu Dian Sawitri', Ni Ketut Supasti Dharmawan²}

\author{
1ZIV Law Office, E-mail: dewaayu_dian@ymail.com \\ ${ }^{2}$ Fakultas Hukum Universitas Udayana, E-mail : supasti_dharmawan@unud.ac.id
}

\begin{tabular}{l}
\hline Info Artikel \\
\hline Masuk: 12 Mei 2020 \\
Diterima:9 Juli 2020 \\
Terbit: 31 \\
Keywords : \\
Regulation; Protection; \\
Digitalitation of Lontar; \\
Copyright. \\
\\
\\
Katakunci: \\
Perlindungan; Transformasi; \\
Lontar; Digitalisasi. \\
Corresponding Author: \\
Dewaayu_dian@ymail.com \\
DOI: \\
10.24843/AC.2020.v05.i02.p08 \\
\end{tabular}

\begin{abstract}
The purpose of this study to examine the protection of transformation of lontar copyrighted works in the form of digitalization and the mechanism of legalizing the transformation of works that were originally in the form of lontar. This study uses a socio-legal researchy method which is a mixture of normative legal research methods with empirical legal research methods. This study uses a statutory approachy, conceptuayl approach and facts. The study results show that the regulation of transformation of lontar copyright works in the form of digitalization is regulated in Article 40 paragraph 1 letter $n$ of the Copyright Law which is made possible through an expanded interpretation. It can be stated that the transformation also includes works of traditional cultural expression. The process oflegalizing the transformation is included in Article 26 paragraph (1) of the Cultural Promotion Act which explains that the Central Government and the Regional Government are obliged to save the Cultural Promotion Object. Transformation of lontar into the form of digitization is one form of saving against lontar but in the process of this transformation muststill refer to the agreement of the owner of the lontar work.
\end{abstract}

\begin{tabular}{l}
\hline Abstrak \\
\hline Tujuan studi ini untuk mengkaji perlindungan transformasi \\
karya cipta lontar dalam bentuk digitalisasi serta mekanisme \\
legalisasi pentransformasian dari karya yang awalnya berbentuk \\
lontar. Studi ini menggunakan metode penelitian sosio-legal \\
yang merupakan campuran dari metode penelitian hukum \\
normatif dengan metode penelitian hukum empiris. Studi ini \\
menggunakan pendekatan perundang-undangan, pendekatan \\
konseptual dan fakta. Hasil studi menunjukkan bahwa \\
pengaturan transformasi karya cipta lontar dalam bentuk \\
digitalisasi diaturdalam Pasal 40 ayat 1 hurufn UU Hak Cipta \\
yang dimungkinkan melalui suatu penafsiran yang diperluas \\
dapat dikemukakan bahwa transformasi juga mencakup karya \\
ekspresi budaya tradisional. Proses legalisasi transformasi \\
termasuk dalam Pasal 26 ayat 1 Undang-Undang Pemajuan \\
Kebudayaan yang menjelaskan bahwa Pemerintah Pusat \\
danjatau Pemerintah Daerah penyelamatan dilakukan wajib \\
Objek Pemajuan Kebudayaan. Transformasi lontar ke dalam \\
bentuk digitalisasi merupakan salah satu bentuk penyelamatan \\
terhadaplontar tetapidalamproses transformasi ini harus tetap
\end{tabular}


mengacu pada persetujuan dari pemilik karya lontar.

\section{Pendahuluan}

Menurut Carolyn Hotckis dalam "International Law for Bussines" yang dikutip oleh Maria Alfons, bahwa saat ini "sistem hukum meletakkan kekayaan kedalam tiga kategori, pertama, sebagian besar masyarakat mengakui hak kepemilikan pribadi dalam kekayaan pribadi, yang dikenal dengan intangible things; kedua, kekayaan dalam pengertian riil seperti tanah dan bangunan; dan ketiga, kekayaan yang diketahui sebagai kekayaan intelektual." Terkait dengan KI, hak kekayaan diakui semua negara produk bentuk dalam ide, seperti dalam bentuk hak cipta, paten, merek dan rahasia dagang, tata letak sirkuit terpadu, varietas tanaman. ${ }^{1}$ Secara faktual, Hak Kekayaan Intelektual merupakan "satu sistem pemberian perlindungan hukum bagi karya-karya intelektual yang mencakup jangkauan yang luas, dari pengetahuan tradisional sampai program komputer dan Internet di era bisnis digital saat ini." Hak Kekayaan Intelektual merupakan "hak untuk menikmati hasil kreativitas intelektual manusia secara ekonomis."2

Hak Kekayaan Intelektual sangat penting memperoleh perlindungan, hal ini karena hak kekayaan intelektual merupakan hak yang timbul dari kekayaan yang diciptakan oleh kreativitas dan olah pikir intelektual manusia. Manusia terlahir dengan cipta dan karsa sehingga adanya kreativitas dalam diri manusia yang mampu melahirkan karya-karya intelektual. ${ }^{3}$ Karya-karya intelektual tersebut memiliki nilai ekonomi dan bermanfaat bagi kehidupan manusia dalam meningkatkan kekayaan. Indonesia pada zaman dahulu tidak mengenal adanya perlindungan terhadap kekayaan intelektual. Berakar dari negara maju yang memiliki pengaturan perundang-undangan terkait hak kekayaan intelektual. Pengaturan terkait hak kekayaan intelektual disepakati melalui berbagai konvensi Internasional. Pada 1 Januari 1995, Indonesia terdaftar sebagai negara anggota World Trade Organization (Selanjutnya disebut WTO) sehingga Indonesia kewajiban dimiliki untuk menaati TRIPs Agreement dengan merevisi perundang-undangan di bidang kekayaan intelektual. Undang-Undang yang berkaitan dengan kekayaan intelektual di Indonesia.

Digitalisasi lontar adalah upaya yang mengubah media lontar ke bentuk digital digital gambar atau mesin terbang digital. Digitalisasi lontar dilakukan untuk mendapatkan hasil dalam bentuk gambar digital. Bisa dikatakan teknologi menjadi sarana untuk mendokumentasikan, melestarikan, melestarikan dan penyebaran budaya. Hasil dari digitalisasi lontar ini adalah gambar digital yang menjadi dokumentasi dari lontar asli. Dengan memiliki dokumentasi berarti lontar telah dilestarikan karena ada salinan lontar asli sehingga salinan tersebut dapat disalin secara bebas dibentuk digital. Pelestarian lontar dengan melakukan digitalisasi lontar dapat menyebarkan budaya melalui lontar

${ }^{1}$ Alfons, M. (2017). Implementasi hak kekayaan intelektual dalam perspektif negara hukum. Jurnal Legislasi Indonesia, 14(3),301-311.DOI:https://doi.org/10.333069/jsh.24.2.164178

${ }^{2}$ Nugroho, S. (2015). Perlindungan Hak Kekayaan Intelektual Dalam Upaya Peningkatan Pembangunan Ekonomi Di Era Pasar Bebas ASEAN. Supremasi Hukum: Jurnal Penelitian Hukum, 24(2), 164-178.

${ }^{3}$ Dharmawan, N. K. S. (2018). Harmonisasi hukum kekayaan intelektual Indonesia. Swasta Nulus. 
dalam bentuk digital gambar. Proses digitalisasi lontar dilakukan dengan beberapa tahapan di antaranya: (1) akuisisi data adalah proses untuk mendapatkan data dalam bentuk gambar, dalam penelitian ini menggunakan kamera digital; (2) gambar kemudian dapatkan pengolahan gambar perawatan menggunakan komputer lengkap dengan aplikasi gambar; (3) gambar yang telah diproses gambar dapat disimpan di penyimpanan digital media sebagai arsip jika sewaktu-waktu diperlukan melakukan pemrosesan pengembalian atau untuk tujuan tersebut disebarluaskan melalui transfer data digital; (4) gambar yang telah diproses secara digital kemudian dapat dilihat di layar penampil atau dicetak ulang menggunakan gambar printer. ${ }^{4}$ Proses digitalisasi dokumen merupakan "proses perubahan dari dokumen tercetak menjadi dokumen elektronik."5 Proses digitalisasi pada dokumen ini juga dilakukan pada lontar.

Lontar merupakan salah satu karya sastra yang berisikan ilmu pengetahuan yang sudah ada sejak zaman dahulu. Segala jenis ilmu pengetahuan, seni dan sastra dilindungi Hak Cipta sejak ciptaan tersebut diwujudkan. ${ }^{6}$ Begitu juga dengan Lontar yang merupakan salah satu karya sastra sudah tentu mendapatkan hak cipta sejak lontar tersebut diwujudkan. Selain lontar, digitalisasi lontar juga sudah seharusnya mendapat perlindungan hukum karena digitalisasi lontar merupakan perwujudan karya sastra dalam bentuk digital. Namun secara eksplisit UU Hak Cipta belum mengatur mengenaiperlindungan terkait digitalisasi lontar. Disisi lain, digitalisasi lontar merupakan hasil olah pikir intelektual manusia yang memiliki nilai ekonomis sehingga berhak mendapatkan perlindungan hukum.

Berdasarkan latar belakang tersebut, penting untuk dikaji terkait "Perlindungan Transformasi Karya Cipta Lontar Dalam Bentuk Digitalisasi". Adapun permasalahan yang dapat ditarik dari pemaparan latar berlakang diatas ialah sebagai berikut: Bagaimanakah perlindungan transformasi karya cipta lontar dalam bentuk digitalisasi serta Bagaimana mekanisme legalisasi pentransformasian dari karya yang awalnya berbentuk lontar. Studi ini bertujuan untuk mengkaji perlindungan transformasi karya cipta lontar dalam bentuk digitalisasi serta mengelaborasi mekanisme legalisasi pentransformasian dari karya yang awalnya berbentuk lontar.

\section{Metode Penelitian}

Studi ini menggunakan metode penelitian sosio-legal yang merupakan "kombinasi antara metode penelitian hukum doktriner dan metode penelitian hukum empirik (yang meminjam metode ilmu sosial), maka yang dilakukan peneliti adalah studi dokumen, yang disertai dengan studi lapangan." 7 dengan pendekatan perundang-undangan (statue approach), pendekatan konseptual (conceptual approach), pendekatan fakta (fact

${ }^{4}$ Bahar,H., \& Mathar, T. (2015). Upaya Pelestarian Naskah Kuno di Badan Perpustakaan dan Arsip Daerah Provinsi Sulawesi Selatan. Khizanah al-Hikmah: Turnal Ilmu Perpustakaan, Informasi, dan Kearsipan, 3(1), 89-100. DOI : https://doi.org/10.204252/kah.v3i1a8

5 Sudiar, N., Mafar, F., \& Rosman, H. (2017). Dari PDf Ke Flipping Manuscript: Upava Kemas Ulang HasilKatalogisasi Naskah Kuno Melayu di Provinsi Riau. Manuskripta, 7(2), 21-31. DOI : https://doi.org/10.330656/manuskripta.v7i2.92

${ }^{6}$ Mulyani, S. (2012). Pengembangan Hak Kekayaan Intelektual sebagai Collateral (Agunan) Untuk Mendapatkan Kredit Perbankan di Indonesia. Jurnal Dinamika Hukum, 12(3), 568-578. DOI : $\underline{\text { http:// dx.doi.org/10.020884/1.jdh.2012.12.3.128 }}$

7Irianto, S. (2011). Praktik Penelitian Hukum: Perspektif Sosiolegal. Metode Penelitian Hukum: Konstelasi dan Refleksi. Jakarta: Yayasan Obor Indonesia. 
approach). Pengumpulan bahan hukum dalam studi ini ialah teknik kepustakaan. Analisis dalam studi ini menggunakan teknik deskripsi pada bahan hukum primer dan bahan hukum sekunder berupa buku-buku literatur yang menunjang studi ini yang telah dikumpulkan kemudian dikaitkan dengan teori serta literatur hukum sehingga dapat membantu dalam studi ini.

\section{Hasil Dan Pembahasan}

\subsection{Perlindungan Transformasi Karya Cipta Lontar Dalam Bentuk Digitalisasi}

Lontar merupakan "salah satu karya sastra yang berisikan ilmu pengetahuan yang sudah ada sejak zaman dahulu. Segala jenis ilmu pengetahuan, seni dan sastra dilindungi Hak Cipta sejak ciptaan tersebut diwujudkan." 8 Begitu juga dengan Lontar yang merupakan salah satu karya sastra sudah tentu mendapatkan hak cipta sejak lontar tersebut diwujudkan. Selain lontar, digitalisasi lontar juga sudah seharusnya mendapat perlindungan hukum karena digitalisasi lontar merupakan perwujudan karya sastra dalam bentuk digital.

Kemajuan teknologi dan informasi yang cepat dapat menyebabkan lontar kurang diperhatikan bahkan akan terlupakan. Kebanyakan orang memiliki kecenderungan untuk melakukannya menganggap lontar adalah benda kuno dan milik tidak ada manfaat nilai lagi bagi mereka dibandingkan dengan menggunakan peralatan canggih tersedia hari ini. Keberadaan lontar akan lebih mengkhawatirkan saat nilai-nilai luhur terkandung di dalamnya diakui dan dipatenkan oleh pihak lain kemudian orang mulai dikejutkan kembali dan mulai dari awal untuk menjaga budaya. Sains dan teknologi informasi tidak hanya memberi kesenangan yang mengubah tatanan kehidupan manusia, tetapi bisa menjadi dasar inovasi ke lontar. Lontar digitalisasi adalah inovasi dengan memanfaatkan ilmu pengetahuan dan teknologi untuk mengkonversi lontar menjadi bentuk digital baik fotografi atau naskahnya. Konversi lontar menjadi bentuk digital sangat penting di era ini berbasis informasi. Bahkan lebih signifikan hasil digitalisasi lontar miliki manfaat dalam kehidupan sehari-hari terutama di bidang pendidikan. Ilmu pengetahuan bisa disebarluaskan melalui pendidikan sehingga dapat membina manusia rasa diri. Rasa diri manusia adalah instrumental dalam memilah dan memilih yang baik manfaat dan bermanfaat bagi diri mereka sendiri dan masyarakat pada umumnya.

Secara eksplisit, UU Hak Cipta belum mengatur mengenai perlindungan terkait digitalisasi lontar. Disisi lain, digitalisasi lontar merupakan hasil olah pikir intelektual manusia yang memiliki nilai ekonomis sehingga berhak mendapatkan perlindungan hukum.

Kepentingan hukum adalah "mengurusi hak dan kepentingan manusia, sehingga hukum memiliki otoritas tertinggi untuk menentukan kepentingan manusia yang perlu diatur dan dilindungi." Perlindungan Hukum menurut C.S.T Kansil adalah "penyempitan arti dari perlindungan, dalam hal ini hanya perlindungan oleh hukum saja." Menurutnya bahwa "diberikan oleh hukum yang perlindungan, adanya hak dan kewajiban dengan pula terkait, manusia dimiliki ini hal dalam sebagai subyek hukum

${ }^{8}$ Mulyani, S. (2012). Pengembangan Hak Kekayaan Intelektual sebagai Collateral (Agunan) Untuk Mendapatkan Kredit Perbankan di Indonesia. Jurnal Dinamika Hukum, 12(3), 568-578. DOI : http://dx.doi.org/10.208874/1.jdh.2012.12.3.128 
dalam interaksinya dengan hukum manusia serta lingkungannya. hak dan kewajiban dimiliki sebagai subyek hukum manusia untuk suatu dilakukan tindakan hukum." 9 Robert C. Sherwood sebagaimana dikutip oleh Muhammad Fahmi Rois, Kholis Roisah ${ }^{10}$ mengatakan bahwa "pelaku industri kreatif mendapatkan perlindungan melalui reward theory, recovery theory, incentive theory, risk theory, dan economic growth stimulus theory." Konsep tersebut masing-masing adalah: "reward theory yaitu pencipta mendapatkan imbalan terhadap karya intelektual sebagai pengakuan dan penghargaan atas upaya kreatifnya." Kedua, "recovery theory: berdasarkan teori ini, pencipta atau pelaku ekonomi kreatif seharusnya memperoleh kembali apa yang dikeluarkan." Ketiga, "incentive theory: menyatakan bahwa insentif sangat penting untuk memacu pelaku ekonomi kreatif semakin meningkatkan karyanya intelektualnya." Keempat, "risk theory: teori ini mengakui bahwa suatu ciptaan memiliki risiko untuk ditiru oleh orang lain." Untuk itu sudah seharusnya ciptaan perlindungan hokum diperoleh. Kelima, "economic growth stimulus theory: pertumbuhan ekonomi dapat dilihat dari kemampuan industri kreatif sebagai industri berbasis HKI dapat menciptakan lapangan usaha dan meningkatkan perekonomian sektor riil."

Lontar adalah "teks warisan leluhur yang berisikan purana sebagai bagian dari Weda Smerti khususnya dalam kelompok Upaweda sebagai kitab suci umat Hindu Dharma yang disebutkan tidak akan pernah musnah selama kehidupan ini masih eksis." 11 Lontar dibuat dari bahan yang mudah lapuk sehingga sangat mungkin akan musnah dikemudian hari apabila tidak dilakukan pelestarian terhadap lontar tersebut. Hal ini juga termuat dalam ketentuan Pasal 5 UU Pemajuan Kebudayaan yang menjelaskan bahwa manuskrip merupakan salah satu Objek Pemajuan Kebudayaan. Menurut Pasal 1 angka 3 UU Pemajuan Kebudayaan dijelaskan bahwa "Pemajuan Kebudayaan adalah Pemajuan Kebudayaan adalah upaya meningkatkanketahanan budaya dan kontribusi budaya Indonesiadi tengah peradaban dunia melalui Pelindungan,Pengembangan, Pemanfaatan, dan Pembinaan Kebudayaan."

Pengaturan mengenai pentingnya pemajuan terhadap kebudayaan terutama terhadap manuskrip (atau yang sering disebut dengan lontar) memperlihatkan bahwa pentingnya dilaksanakan pengembangan terhadap lontar tersebut agar tidak punah dikemudian hari. Dapat cara salah satu dilakukan untuk pengembangan terhadap karya lontar ini ialah digitalisasi lontar.

Digitalisasi adalah "proses alih media dari bentuk tercetak, audio, maupun video menjadi bentuk digital. Digitalisasi dilakukan untuk membuat arsip dokumen bentuk digital, untuk fungsifotokopi, dan untuk membuat koleksi perpustakaan digital." 12

${ }^{9}$ Turatmiyah, S., \& Annalisa, Y. (2013). Pengakuan hak-hak perempuan sebagai pekerja rumah tangga (domestic workers) sebagai bentuk perlindungan hukum menurut hukum positif Indonesia. Jurnal Dinamika Hukum, 13(1), 49-58. DOI http:// dx.doi.org/10.208684/1.jdh.2013.13.1.155

10Rois, M. F., \& Roisah, K. (2018). Perlindungan Hukum Kekayaan Intelektual Kerajinan Kuningan Tumang. Kanun: Jurnal Ilmu Hukum,20(3), 401-419.doi: https://doi.org/10.24815/kanun.v20i3.11717, p. 401-419.

11Sejarah Hari Raya dan Upacara Yadnya di Bali.Lontar.http:// sejarahharirayahindu.blogspot.com/2012/05/lontar.html, diakses tanggal 20 Oktober 2019, pukul 10.00 WITA.

${ }^{12}$ Anwar, M. T., Husain, H., \& Jaya, N. N. (2018). Preservasi Naskah Kuno Sasak Lombok Berbasis Digital dan Website. Jurnal Teknologi Informasidan Ilmu Komputer, 5(4), 445-454. DOI : http://dx.doi.org/10.254126/jtiik.201854787 
Peralatan diperlukan digitalisasi seperti komputer, scanner, operator media sumber dan software pendukung program bantuan scanning dokumen seperti Adobe Acrobat dan Omnipage. ${ }^{13}$

Menurut Terry Kuny “digitalisasi adalah mengacu pada proses menterjemahkan suatu potongan informasi seperti sebuah buku, rekaman suara, gambar atau video, ke dalam bit-bit." Bit adalah "satuan dasar informasi di dalam suatu sistem komputer." Sedangkan menurut Marilyn Deegan "digitalisasi adalah proses konversi dari segala bentuk dokumen tercetak atau yang lain ke dalam penyajian bentuk digital". ${ }^{14}$

Dalam bidang perpustakaan, proses digitalisasi adalah "kegiatan mengubah dokumen tercetak menjadi dokumen digital." Digitalisasi Lontar adalah "proses alih media Lontar dari bentuk tercetak, menjadi bentuk digital."15 Digitalisasi Lontar dilakukan untuk membuat arsip Lontar dalam bentuk digital sehingga mudah disimpan dan tidak mudah lapuk dimakan waktu. Seperti yang kita ketahui segala jenis ilmu pengetahuan, seni dan sastra dilindungi Hak Cipta sejak ciptaan tersebut diwujudkan. Begitu juga dengan Lontar yang sudah tentu mendapatkan hak cipta sejak lontar tersebut diwujudkan.

Digitalisasi lontar merupakan salah satu karya seni dan sastra yang membutuhkan kepastian hukum berupa hak cipta sehingga digitalisasi lontar tidak mudah dijiplak dikemudian hari. Hal ini karena dalam sistem perlindungan hak cipta secara otomatis perlindungan (automatically protection) sistem dianut yang mana tidak mewajibkan adanya proses pencatatan. ${ }^{16}$ Dengan kata lain, proses pencatatan atau pendaftaran dilalui tanpa terlebih dahulu, secara sudah pencipta otomatis perlindungan hukum didapat atas karya ciptanya begitu karya tersebut bentuk dalam karya cipta nyata diwujudkan sudah. ${ }^{17}$ Meskipun sebuah ciptaan otomatis mendapat hak cipta sejak ciptaan itu ada, penting untuk melakukan pencatatan agar pencipta mendapat perlindungan berupa hak eksklusif terkait pemanfaatan ciptaan tersebut dalam bentuk hak moral maupun hak ekonomi. Hak eksklusif yang diperoleh pencipta ini merupakan salah satu bentuk reward bagi pencipta yang waktu diluangkan telah dan ide kreatifnya untuk membuat suatu ciptaan. Hal ini sesuai dengan teori perlindungan dalam hak cipta yaitu Reward Theory.

Menurut ketentuan Pasal 40 ayat 1 Undang-Undang Nomor 28 Tahun 2014 Tentang Hak Cipta yang menjelaskan Ciptaan yang dilindungi meliputi Ciptaan dalam bidang ilmu pengetahuan, seni dan sastra, terdiri atas: "Buku, pamflet perwajahan karya tulis yang diterbitkan, dan semua hasil karya tulis lainnya;Ceramah, kuliah, pidato, dan Ciptaan sejenis lainnya;Alat peraga yang dibuat untuk kepentingan pendidikan dan ilmu

\footnotetext{
${ }^{13}$ Latiar, H. (2018). Preservasi Naskah Kuno Sebagai Upava Pelestarian Budava Bangsa. AlKuttab: Jurnal Perpustakaan dan Informasi,5(1), 67-84. DOI : https:// doi.org/10.234952/ktb.v5i1.827

${ }^{14}$ Ibid.

${ }^{15}$ Setiadi, I. K. Y., Sudarma, M., \& Khrisne, D. C. (2018). Sistem Pencarian Lontar Berbasis Web Dengan Metode Vector Space Model Pada Dinas Kebudayaan Provinsi Bali. Iurnal Spektrum, 5(2), 239-245. DOI : https:// doi.org/10.248643/SPEKTRUM.2018.v05.i02.p30

${ }^{16}$ Dosi, I. H., Santoso, B., \& Njatrijani, R. (2017). Aspek Hukum Perlindungan Hak Cipta Program Komputer Di Dalam Creative Commons Indonesia. Diponegoro Law Journal, 6(2), 120.

17Mahartha, A. (2018). Pengalihwujudan Karya Sinematografi Menjadi Video Parodi Dengan Tujuan Komersial Perspektif Perlindungan Hak Cipta. Kertha Patrika, 40(01), 13-23.
} 
pengetahuan;Lagu dan/atau music dengan atau tanpa teks;Drama, drama musical, tari, koreografi, pewayangan, dan pantomime;Karya seni rupa dalam segala bentuk seperti lukisan, gambar, ukiran, kaligrafi, seni pahat, patung atau kolase;Karya seni terapan;Karya arsitektur;Peta;Karya seni batik atau seni motif lain; Karya fotografi; Potret;Karya sinematografi;Terjemahan, tafsir, saduran, bunga rampai, basis data, adaptasi, aransemen, modifikasi dan karya lain dari hasil transformasi;Terjemahan, adaptasi, aransemen, transformasi, atau modifikasi ekspresi budaya tradisional;Kompilasi ciptaan atau data, baik dalam format yang dapat dibaca dengan Program Komputer maupun media lainnya;Kompilasi ekspresi budaya tradisional selama kompilasi tersebut merupakan karya yang asli;Permainan video; dan Program Komputer."

Dari penjelasan Pasal tersebut diatas tidak dijelaskan secara ekplisit mengenai perlindungan terhadap karya hasil digitalisasi. Dalam penjelasan Pasal 40 ayat (1) Undang-Undang Hak Cipta dalam setiap penjelasannya tidak menjelaskan atau memberi pengertian bahwa adanya karya digitalisasi yang mendapat perlindungan hak cipta. Namun sama halnya dengan lontar, digitalisasi lontar tentunya mendapat perlindungan hak cipta sejak digitalisasi lontar diwujudkan.

Menurut penjelasan Pasal 40 ayat 1 huruf n Undang-Undang Hak Cipta dijelaskan bahwa "salah satu ciptaan yang dilindungi ialah karya lain dari hasil transformasi." Hal ini bisa ditafsirkan sebagai penjelasan dari karya hasil digitalisasi.Begitu pula digitalisasi lontar yang dapat dikatakan sebagai hasil transformasi karena digitalisasi lontar awalnya merupakan sebuah lontar tercetak diubah menjadi ke bentuk digital.

\subsection{Mekanisme Legalisasi Pentransformasian Karya Yang Awalnya Berbentuk Lontar}

Digitalisasi Lontar merupakan transformasi dari karya yang awalnya berbentuk lontar dan dilakukan guna perlindungan dan pengembangan terhadap lontar tersebut sebagai wujud pemajuan kebudayaan. ${ }^{18}$ Lontar pada umumnya merupakan hak milik komunal dan menjadi milik negara apabila tidak diketahui penulisnya. Hal ini termuat dalam ketentuan Pasal 38 ayat (1) UU Hak Cipta yang menjelaskan bahwa "Hak Cipta atas Ekspresi Budaya Tradisional dipegang oleh Negara". Negara wajib melakukan inventarisasi, menjaga dan melindungi ekspresti budaya tradisional. Hal ini juga sesuai dengan ketentuan dalam Pasal 5 UU Pemajuan Kebudayaan yang menjelaskan bahwa manuskrip merupakan salah satu Objek Pemajuan Kebudayaan. Menurut Pasal 1 angka 3 UU Pemajuan Kebudayaan dijelaskan bahwa "Pemajuan Kebudayaan adalah Pemajuan Kebudayaan adalah upaya meningkatkan ketahanan budaya dan kontribusi budaya Indonesia di tengah peradaban dunia melalui Perlindungan, Pengembangan, Pemanfaatan, dan Pembinaan Kebudayaan". Pengaturan mengenai pentingnya pemajuan terhadap kebudayaan terutama terhadap manuskrip (atau yang sering disebut dengan lontar) memperlihatkan bahwa pentingnya dilaksanakan pengembangan terhadap lontar tersebut agar tidak punah dikemudian hari. Salah satu cara yang dapat dilakukan untuk perlindungan dan pengembangan terhadap karya lontar ini ialah digitalisasi lontar. Selain itu digitalisasi lontar juga dapat menjadi

${ }^{18 B I N T, ~ K . ~ A . ~ S . ~(2015) . ~ D e k o n s t r u k s i ~ s a s t r a ~ l o n t a r ~ d i ~ e r a ~ g l o b a l i s a s i ~(p e r s p e k t i f ~ k a j i a n ~}$ budaya). (Doctoral dissertation, Universitas Gadjah Mada). 
sarana untuk menjaga dan menginventarisasi lontar sebagai ekspresi budaya tradisional.

Adapun proses digitalisasi lontar dibutuhkan alat-alat yaitu Kamera; Tripod; Lampu untuk pencahayaan. Satu set computer atau laptop dengan softwarenya Second battery; Kabel ekstension; Kain latar (sesuai keinginan); Kaca; Colour checker dan penggaris; Pengganjal penyeimbang. Setelah alat-alat tersebut siap, maka prosedur digitalisasi lontar sudah bisa dilaksanakan.Adapun prosedurnya yaitu Membersihkan Lontar selanjutnya Dilakukan pemotretan halaman demi halaman lontar. Pemotretan dilakukan dengan menggunakan kamera dibantu dengan lighting untuk pencahayaan yang bagus sehingga mendapat hasil yang sempurna.Selain itu, bisa juga menggunakan kain latar untuk hasil foto yang lebih artistic. ${ }^{19}$

Lontar merupakan ekpresi budaya tradisional yang hak ciptanya dipegang oleh negara. Dengan kata lain, setiap lontar merupakan milik pemerintah dimana lontar itu berada, termasuk Lontar di Provinsi Bali yang hak ciptanya dipegang oleh Dinas Kebudayaan Provinsi Bali. Berdasarkan wawancara langsung dengan Bapak Made Mahesa Yuma Putra selaku Kepala Seksi Inventarisasi dan Pemeliharaan Dokumentasi Kebudayaan dari Dinas Kebudayaan Provinsi Bali dijelaskan bahwa lontar-lontar yang berada di Ruangan Lontar Dinas Kebudayaan Provinsi Bali terdiri dari lontar tanpa pencipta dan lontar dengan pencipta. Lontar tanpa pencipta ini ada beberapa yang sudah dilakukan digitalisasi seperti kakawin Arjuna Wiwaha, Bomantaka, Parwa, Kidung, Babad, Wariga, Geguritan, dan juga pipil tanah yang mana lontar ini sudah berumur 1700 saka atau tahun 1778 Masehi.

Proses digitalisasi untuk lontar tanpa pencipta ini dilakukan langsung oleh Dinas Kebudayaan Provinsi Bali dengan menggandeng Digital Repository of Endangered and Affected Manuscript in Southeast Asia (DREAMS) dalam proses digitalisasi ini, hal ini karena lontar tanpa pencipta merupakan hak ciptanya dipegang oleh Dinas Kebudayaan Provinsi Bali sehingga dalam hal perlindungan dan pengembangan lontar tersebut menjadi tanggung jawab Dinas Kebudayaan Provinsi Bali. Sedangkan untuk lontar yang ada penciptanya namun lontar tersebut ditempatkan di Dinas Kebudayaan Provinsi Bali, apabila lontar tersebut akan didigitalisasi, pihak Dinas Kebudayaan wajib meminta ijin terlebih dahulu kepada pencipta lontar tersebut.

Pertimbangan ekonomi pada digitalisasi lontar dalam hal waktu, kapan pun lontar dibaca, dengan demikian, ia menjadi pedoman dasar di mana dan ketika lontar yang dibutuhkan adalah digital tanpa datang ke suatu tempat karena digitalisasi lontar disalin lebih cepat. Pertimbangan hukum yang mendasari adalah pusat studi lontar di Universitas Udayana di Denpasar adalah digitalisasi lontar. Ini mengusulkan hak kekayaan intelektual atas nama lembaga ketika penting hasil digitalisasi mendapatkan hak cipta, sehingga artinya lontar dilindungi. Program digitalisasi lontar dilakukan berdasarkan kesadaran dan nyata. Pertimbangan pentingnya rasional dalam penggunaan kecanggihan teknologi untuk mencapai tujuan. Hal ini juga disertai dengan strategi untuk mencapai tujuan. Kemajuan teknologi dapat berguna untuk menyelamatkan lontar. Sudah rusak. Dengan demikian, literatur yang bermanfaat dapat diselamatkan. Peran digitalisasi lontar sangat positif untuk stabilitas dan kelestarian budaya di bidang sastra Bali, khususnya, pengembangan nasional

19Prasetyo, A., \& Setiawan, A. H. (2016). Digitalisasi Sebagai Upaya Penyelamatan Dan Kemudahan Akses Naskah Kuno. Prosiding: Seni, Teknologi, Dan Masyarakat, (1), 42-48. 
pelestarian lontar. Digitalisasi adalah salah satu cara pelestarian karena lontar berasal dari alam yang tidak dapat diprediksi. Padahal, jika perawatan lontar baik, ada lontar hingga empat ratus tahun dan ada lebih dari itu. Jika proses pembuatan lontar tidak baik, kemungkinan usia naskah tidak akan bertahan lama. Di sinilah peran digitalisasi lontar untuk menyelamatkan lontar dari kerusakan. Mengenai konten digitalisasi dipertahankan dan dapat disalin lagi bahkan jika lontar fisik rusak. Teknik digitalisasi dimulai dari proses manuskrip lontar konservasi mendefinisikan pembersihan naskah lontar. Dalam proses ini, naskah lontar dibersihkan, sehingga dapat dibaca. Pada proses pertama, yaitu membersihkan lontar, huruf-huruf dari naskah lontar akan didigitalkan dapat terlihat dengan jelas.

Legalitas digitalisasi lontar ini merupakan salah satu wujud penyelematan objek pemajuan kebudayaan, hal ini sesuai dengan ketentuan dalam Pasal 26 ayat 1 UndangUndang No. 5 Tahun 2007 Tentang Pemajuan Kebudayaan yang menjelaskan bahwa "Pemerintah Pusat dan atau Pemerintah Daerahwajib melakukan penyelamatan Objek Pemajuan Kebudayaan". Selain lontar yang hak ciptanya di pegang oleh negara dan hasil digitalisasi terhadap lontar itu nantinya juga akan menjadi milik negara. Ada beberapa lontar yang didigitalisasi oleh individu perorangan. Dalam penelitian langsung di Sentra Hak Kekayaan Intelektual Universitas Udayana ditemukan bahwa ada beberapa lontar yang didigitalisasi oleh Fakultas Ilmu dan Budaya Universitas Udayana. Digitalisasi Lontar ini dicatatkan hak ciptanya atas nama Dekan Fakultas Ilmu dan Budaya Universitas Udayana yaitu Ibu Ni Luh Putu Sutjiati Berata. Hak cipta atas digitalisasi lontar ini didaftarkan atas ide dan kreativitas orang tersebut dalam melakukan digitalisasi terhadap lontar-lontar tersebut.

\section{Kesimpulan}

Berdasarkan hasil dan pembahasan yang telah dipaparkan diatas, diperoleh kesimpulan bahwaPerlindungan transformasi karya cipta lontar dalam bentuk digitalisasi termuat dalam Undang-Undang Hak Cipta. Meskipun tidak eksplisit disebutkan dalam ketentuan undang-undang tersebut, namun karya digitalisasi lontar merupakan sebuah karya seni, pengetahuan dan sastra yang telah mendapat perlindungan sejak ciptaan itu lahir. Perlindungan digitalisasi lontar termuat dalam Pasal 40 ayat 1 huruf n UU Hak Cipta yang dimungkinkan melalui suatu penafsiran yang diperluas dapat dikemukakan bahwa transformasi juga mencakup karya ekspresi budaya tradisional.Proses legalisasi transformasi termasuk dalam Pasal 26 UndangUndang Pemajuan Kebudayaan yang menjelaskan bahwa Pemerintah Pusat dan atau Pemerintah Daerah penyelamatan dilakukan wajib Objek Pemajuan Kebudayaan. Transformasi lontar ke dalam bentuk digitalisasi merupakan salah satu bentuk penyelamatan terhadap lontar tetapi dalam proses transformasi ini harus tetap mengacu pada persetujuan dari pemilik karya lontar.

\section{Daftar Pustaka}

$\underline{\text { Buku }}$

Dharmawan, N. K. S. (2018). Harmonisas hukum kekayaan intelektual Indonesia.Swasta Nulus. 
Irianto, S. (2011). Praktik Penelitian Hukum: Perspektif Sosiolegal. Metode Penelitian Hukum: Konstelasi dan Refleksi. Jakarta: Yayasan Obor Indonesia.

\section{Jurnal}

Alfons, M. (2017). Implementasi hak kekayaan intelektual dalam perspektif negara hukum Jurnal Legislasi Indonesia, 14(3), 301-311.DOI : https://doi.org/10.330369/jsh.24.2.164-178

Anwar, M. T., Husain, H., \& Jaya, N. N. (2018). Preservasi Naskah Kuno Sasak Lombok Berbasis Digital dan Website. Iurnal Teknologi Informasi dan Ilmu Komputer, 5(4), 445-454.DOI : http://dx.doi.org/10.250126/itiik.201854787

Bahar, H., \& Mathar, T. (2015). Upaya Pelestarian Naskah Kuno di Badan Perpustakaan dan Arsip Daerah Provinsi Sulawesi Selatan. Khizanah alHikmah: Jurnal Ilmu Perpustakaan, Informasi, dan Kearsipan, 3(1), 89-100. DOI :https://doi.org/10.024252/kah.v3i1a8

Dosi, I. H., Santoso, B., \& Njatrijani, R. (2017). Aspek Hukum Perlindungan Hak Cipta Program Komputer Di Dalam Creative Commons Indonesia. Diponegoro Law Journal, 6(2), 1-20.

Latiar, H. (2018). Preservasi Naskah Kuno Sebagai Upaya Pelestarian Budaya Bangsa. Al-Kuttab: Jurnal Perpustakaan dan Informasi, 5(1), 67-84. DOI : https://doi.org/10.249052/ktb.v5i1.827

Mahartha, A. (2018). Pengalihwujudan Karya Sinematografi Menjadi Video Parodi Dengan Tujuan Komersial Perspektif Perlindungan Hak Cipta." Kertha Patrika, 40(01), 13-23.

Mulyani, S. (2012). Pengembangan Hak Kekayaan Intelektual sebagai Collateral (Agunan) Untuk Mendapatkan Kredit Perbankan di Indonesia. Jurnal Dinamika Hukum, 12(3), 568- 578.

DOI :http://dx.doi.org/10.208084/1.jdh.2012.12.3.128

Nugroho, S. (2015). Perlindungan Hak Kekayaan Intelektual Dalam Upaya Peningkatan Pembangunan Ekonomi Di Era Pasar Bebas ASEAN. Supremasi Hukum: Jurnal Penelitian Hukum, 24(2), 164-178. DOI :https://doi.org/10.303369/ish.24.2.164-178

Prasetyo, A., \& Setiawan, A. H. (2016). Digitalisasi Sebagai Upaya Penyelamatan Dan Kemudahan Akses Naskah Kuno. Prosiding: Seni, Teknologi, Dan Masyarakat, (1), 42-48.

Rois, M. F., \& Roisah, K. (2018). Perlindungan Hukum Kekayaan Intelektual Kerajinan Kuningan Tumang. Kanun: Jurnal Ilmu Hukum, 20(3), 401-419. doi: https://doi.org/10.240815/kanun.v20i3.11717, p. 401-419.

Setiadi, I. K. Y., Sudarma, M., \& Khrisne, D. C. (2018). Sistem Pencarian Lontar Berbasis Web Dengan Metode Vector Space Model Pada Dinas Kebudayaan Provinsi Bali. Jurnal SPEKTRUM,5(2), 239-245. DOI : https://doi.org/10.240843/SPEKTRUM.2018.v05.i02.p30

Sudiar, N., Mafar, F., \& Rosman, H. (2017). Dari PDf Ke Flipping Manuscript: Upaya Kemas Ulang Hasil Katalogisasi Naskah Kuno Melayu di Provinsi Riau. Manuskripta, 7(2), 2131.DOI :https://doi.org/10.330656/manuskripta.v7i2.92

Turatmiyah, S., \& Annalisa, Y. (2013). Pengakuan hak-hak perempuan sebagai pekerja rumah tangga (domestic workers) sebagai bentuk perlindungan hukum menurut hukum positif Indonesia. Jurnal Dinamika Hukum, 13(1), 49-58. DOI : http://dx.doi.org/10.209884/1.jdh.2013.13.1.155 


\section{Disertasi :}

BINT, K. A. S. (2015). Dekonstruksi sastra lontar di era globalisasi (perspektif kajian budaya) (Doctoral dissertation, Universitas Gadjah Mada).

\section{Website resmi:}

Sejarah Hari Raya dan Upacara Yadnya di Bali. Lontar http://sejarahharirayahindu.blogspot.com/2012/05/lontar.html, diakses tanggal 20 Oktober 2019, pukul 10.00 WITA. 